\title{
Necropsy studies on adult coeliac disease
}

\author{
H. THOMPSON
}

From the Department of Histology and Morbid Anatomy, The General Hospital, Birmingham

SYNOPSIS The distribution of mucosal changes in adult coeliac disease have been studied in 24 cases within four hours of death. There were six patients on a normal diet who showed flat mucosa in the jejunum, convolutions in the middle third, and digitate villi in the terminal ileum. A more extensive distribution of flat mucosa and convolutions involving most of the small intestine was noted in one case. Eighteen patients had been treated with a gluten-free diet and 11 had responded well clinically and histologically. No evidence of flat mucosa was discovery at necropsy in six of these.

Attention is drawn to the high incidence of malignancy in this series (13 out of 24 cases). Other complications of adult coeliac disease are discussed briefly.

The failure to differentiate clearly in the early literature between tropical and non-tropical sprue and the variable time interval between death and necropsy, with the consequent differing degrees of autolysis, have detracted from the value of many reports in the past on the state of the small intestine. It is not therefore surprising that the view that became generally accepted was that put forward by Thaysen (1932), namely, that there were no specific changes and such that were reported were the result of autolysis or secondary phenomena. However, many reports, as was pointed out by Boels and Tverdy (1950), recorded thinning of the bowel wall, ulceration, fibrosis, oedema, or a velvety mucosa. Abnormal villous morphology with broadening and chronic inflammatory changes was described by Paulley (1954) and the presence of small ulcers was reported by Himes, Gabriel, and Adlersberg (1957).

The most important abnormality, the flat mucosa, now generally recognized as characteristic of adult coeliac disease, was made evident following the introduction of the technique of intestinal biopsy (Royer, Croxatto, Biempica, and Balcazar-Morrison, 1955; Shiner, 1956). The localization and extent of the abnormal mucosal appearances were first described by Hourihane (1963) using a 'swiss-roll' preparation when histological examination revealed areas of subtotal villous atrophy alternating with partial villous atrophy extending from the pylorus to the ileocaecal valve. He also noted that villi and

Received for publication 15 March, 1974. crypts had been replaced by hyaline collagen to which attention had been drawn by Adlersberg and Schein (1947). That the lesions were more severe proximally than distally was demonstrated bo MacDonald, Brandborg, Flick, Trier, and Rubi (1964) using a multiple biopsy tube passed the lengt of the small intestine in four patients with untreated coeliac sprue.

The following necropsy studies were carried out to confirm the clinical diagnosis of adult coeliac disease and assess the response to treatment, to exclude other possible causes of malabsorption, and to inquire into the incidence of neoplasia, ulceration, strictures, diaphragms, and other complications.

\section{Material and Methods}

Necropsies were carried out in 24 patients with adult coeliac disease who had been studied clinically for periods varying from three days to 30 years or more before their death. Twenty-one necropsies were carried out within two hours of death, two were performed three hours after death, and one four hours after death. Two main techniques were utilized for preserving the small intestine.

1 The intact small intestine was removed, filled, and distended with $10 \%$ formalin solution and tied off at both ends. After fixation for 24 hours, the specimen was opened and examined. This technique was followed in 19 cases.

2 When adhesions or a perforation were present, then it was necessary to open the small intestine immediately and immerse it in a large container 
filled with $10 \%$ formalin for 24 hours. This procedure was adopted in five cases.

The stomach, duodenum, duodeno-jejunal flexure, and colon were also removed at the same time, opened, and fixed in $10 \%$ formalin. The rest of the necropsy was then proceeded with in the usual way.

After fixation, the measurements of length and circumferential diameter of the small intestine were taken and the site of ulcers, strictures, tumour, and other lesions was determined. Dissecting microscopy was then carried out and measurements were taken to describe the distribution of flat mucosa, convolutions, digitate and leaf villi in the small intestine and duodenum, which was expressed as a percentage of the total length of the small intestine (table I). Gross staining techniques as described by Dymock and Gray (1968) were used in some cases to accentuate the villous architecture or provide greater contrast for photography.

A linear strip of the entire small bowel was taken in 13 cases, divided into suitably sized blocks and processed in numerical order. In the other 11 cases, representative blocks were taken from different segments of the small intestine, numbered, and entered in the diagram to indicate the level of sampling. A histological grading system was used to combine the dissecting microscope appearances and histological state of the villous architecture as described by Roy Choudhury, Cooke, Tan, Banwell, and Smits (1966). This grading system (table II) is correlated with standard terminology describing partial and subtotal

\begin{tabular}{|c|c|c|}
\hline Grade & Dissecting Microscopy & Histology \\
\hline $\begin{array}{l}\text { Normal } \\
1\end{array}$ & $\begin{array}{l}\text { Digitate and leaf villi } \\
\text { Digitate and leaf villi } \\
\text { Ridges, occasional convolutions }\end{array}$ & $\begin{array}{l}\text { Normal } \\
\text { Minor morphological } \\
\text { abnormality }\end{array}$ \\
\hline 2 & $\begin{array}{l}\text { Convolutions, ridges, occasional } \\
\text { leaf and digitate villi }\end{array}$ & $\begin{array}{l}\text { Partial villous } \\
\text { atrophy }\end{array}$ \\
\hline 3 & $\begin{array}{l}\text { Flat or convoluted mucosa } \\
\text { with or without mosaic pattern }\end{array}$ & $\begin{array}{l}\text { Subtotal villous } \\
\text { atrophy }\end{array}$ \\
\hline
\end{tabular}

Table II Correlation between dissecting microscopy and histology

\begin{tabular}{|c|c|c|c|c|c|c|c|c|c|c|c|c|}
\hline \multirow[t]{3}{*}{$\begin{array}{l}\text { Case } \\
\text { No. }\end{array}$} & \multirow[t]{3}{*}{$\operatorname{Sex}$} & \multirow[t]{3}{*}{$\begin{array}{l}\text { Age } \\
\text { (yr) }\end{array}$} & \multirow{3}{*}{$\begin{array}{l}\text { Dura- } \\
\text { tion of } \\
\text { Disease } \\
(y r)\end{array}$} & \multirow{3}{*}{$\begin{array}{l}\text { Years of } \\
\text { Follow Up }\end{array}$} & \multirow[t]{3}{*}{ Diet } & \multirow[t]{3}{*}{$\begin{array}{l}\text { Dura- } \\
\text { tion }\end{array}$} & \multirow[t]{3}{*}{ Response } & \multirow{3}{*}{$\begin{array}{l}\text { Length } \\
\text { of Small } \\
\text { Intestine } \\
(\mathrm{cm})\end{array}$} & \multicolumn{3}{|c|}{$\begin{array}{l}\text { Grade and Gut } \\
\text { Involvement }(\%)\end{array}$} & \multirow[t]{3}{*}{ Cause of Death } \\
\hline & & & & & & & & & $1^{1}$ & 2 & 3 & \\
\hline & & & & & & & & & $\begin{array}{l}\text { Leaf } \\
\text { Dig. }\end{array}$ & Conv. & Flat & \\
\hline 1 & $\mathbf{F}$ & 57 & 15 & 8 & Normal & - & Satisfactory & 239 & 40 & 29 & 31 & $\begin{array}{l}\text { Adult coeliac disease (Wilding et } \\
\text { al, 1964), bronchopneumonia }\end{array}$ \\
\hline 2 & $\mathbf{M}$ & 58 & 16 & $2 / 52$ & Normal & - & N.A. & 395 & 2 & 30 & 68 & $\begin{array}{l}\text { Pulmonary embolus, carcinoma } \\
\text { stomach }\end{array}$ \\
\hline 3 & $\mathbf{M}$ & 38 & 30 & $2 / 52$ & Normal & - & N.A. & 415 & 38 & 32 & 30 & Reticulum cell sarcoma \\
\hline 4 & $\mathbf{F}$ & 56 & 38 & 5 & Normal & - & Good & 355 & 30 & 46 & 25 & Reticulum cell sarcoma \\
\hline 5 & $\mathbf{F}$ & 49 & 22 & 19 & Normal & - & Good & 565 & 33 & 53 & 114 & Carcinoma of rectum \\
\hline 6 & $\mathbf{F}$ & 69 & 12 & 9 & Normal & - & Good & 793 & 45 & 25 & 330 & Cerebral thrombosis \\
\hline 7 & $\mathbf{F}$ & 63 & 17 & 12 & Gluten-free & $8 / 12$ & Satisfactory & 584 & 65 & 25 & 10 & Reticulum cell sarcoma \\
\hline 8 & $\mathbf{F}$ & 35 & 3 & $8 / 12$ & Gluten-free & $3 / 12$ & N.A. & 480 & 37 & 32 & 31 & Reticulum cell sarcoma \\
\hline 9 & $\mathbf{F}$ & 54 & 50 & 16 & Gluten-free & 3 & Poor & 469 & 16 & 14 & 70 & $\begin{array}{l}\text { Thrombosis of dural venous sinus, } \\
\text { bronchopneumonia }\end{array}$ \\
\hline 10 & $\mathbf{M}$ & 50 & 47 & 1 & Gluten-free & 3 & Poor & 一 & 30 & 34 & 36 & $\begin{array}{l}\text { Neuropathy (Cooke and Smith, } \\
\text { 1966), bronchopneumonia }\end{array}$ \\
\hline 11 & $\mathbf{M}$ & 54 & 46 & 1 & Gluten-free & 1 & Poor & 244 & 30 & 17 & 55 & $\begin{array}{l}\text { Small intestinal ulcers, broncho- } \\
\text { pneumonia, Postoperative } \\
\text { chest complications }\end{array}$ \\
\hline 12 & $\mathbf{M}$ & 46 & 40 & 5 & Gluten-free & 5 & Good & 452 & 66 & 35 & 9 & $\begin{array}{l}\text { Carcinoma oesophagus, volvulus } \\
\text { of sigmoid colon }\end{array}$ \\
\hline 13 & $\mathbf{M}$ & 47 & 5 & $6 / 12$ & Gluten-free & $6 / 12$ & N.A. & 631 & 13 & 32 & 55 & Reticulum cell sarcoma \\
\hline 14 & $\mathbf{M}$ & 58 & 40 & 14 & Gluten-free & 12 & Good & 415 & 98 & 2 & 0 & $\begin{array}{l}\text { Renal and intestinal haemorrhage, } \\
\text { cor pulmonale }\end{array}$ \\
\hline 15 & $\mathbf{F}$ & 68 & 7 & 4 & Gluten-free & 4 & Good & 386 & 100 & $\mathbf{0}$ & 0 & $\begin{array}{l}\text { Reticulum cell sarcoma (Cooke, } \\
\text { 1968) }\end{array}$ \\
\hline 16 & $\mathbf{M}$ & 56 & 11 & 9 & Gluten-free & 9 & Good & 270 & 26 & 68 & 6 & Reticulum cell sarcoma \\
\hline 17 & $\mathbf{F}$ & 54 & 10 & $1 / 12$ & Gluten-free & $3 / 12$ & N.A. & 656 & 26 & 16 & 58 & Reticulum cell sarcoma \\
\hline 18 & $\mathbf{F}$ & 78 & 32 & 9 & Gluten-free & 9 & Good & 510 & 94 & 6 & $\mathbf{0}$ & Pulmonary embolus \\
\hline 19 & $\mathbf{F}$ & 55 & 4 & $2 / 12$ & Gluten-free & $2 / 12$ & N.A. & 760 & 28 & 13 & 59 & Volvulus small intestine \\
\hline 20 & $\mathbf{F}$ & 59 & 30 & 30 & Gluten-free & 3 & Good & 415 & 68 & 20 & 12 & Periarteritis nodosa \\
\hline 21 & $\mathbf{M}$ & 58 & 7 & 6 & Gluten-free & 6 & Good & 506 & 95 & 5 & $\mathbf{0}$ & Coronary thrombosis \\
\hline 22 & $\mathbf{F}$ & 58 & 15 & 15 & Gluten-free & $15 / 12$ & Good & 407 & 24 & 69 & 7 & $\begin{array}{l}\text { Aspergillosis pneumonia, } \\
\text { reticulum cell sarcoma }\end{array}$ \\
\hline 23 & $\mathbf{F}$ & 64 & 16 & 4 & Gluten-free & 4 & Good & 823 & 80 & 20 & 0 & $\begin{array}{l}\text { Postoperative aspiration } \\
\text { pneumonia }\end{array}$ \\
\hline 24 & $\mathbf{F}$ & 81 & 70 & 17 & Gluten-free & 15 & Good & 327 & 39 & 61 & 0 & Reticulum cell sarcoma \\
\hline
\end{tabular}

Table I Clinical summary of the cases

${ }^{1}$ Grade 1 includes normal villous pattern as well as minor morphological abnormality. 
villous atrophy. Blocks were also taken from ulcers, strictures, tumours, etc. Finally mesenteric lymph nodes were dissected out and representative nodes were examined histologically.

The diagnosis of adult coeliac disease has been assessed by Cooke (1968) and is based on clinical evidence of the malabsorption syndrome with steatorrhoea (faecal fats in excess of $6 \mathrm{~g}$ per day) together with the demonstration of the characteristic flat mucosa in 21 cases during life and in three at necropsy (cases 2, 3, and 5). Permission for jejunal biopsy had been refused in case 5 . In the other two cases death occurred from malignancy before jejunal biopsy could be arranged. A gluten-free diet was prescribed in 18 cases and duration of the dietary regime and response are listed in table I. A good or satisfactory response to a gluten-free diet indicates clinical biochemical and haematological improvement. No cases of dermatitis herpetiformis are included in this series. Detailed clinical reports in some of these cases are recorded in the literature by Wilding, Cooke, and Nicholson (1964), and Harris, Cooke, Thompson, and Waterhouse (1967).

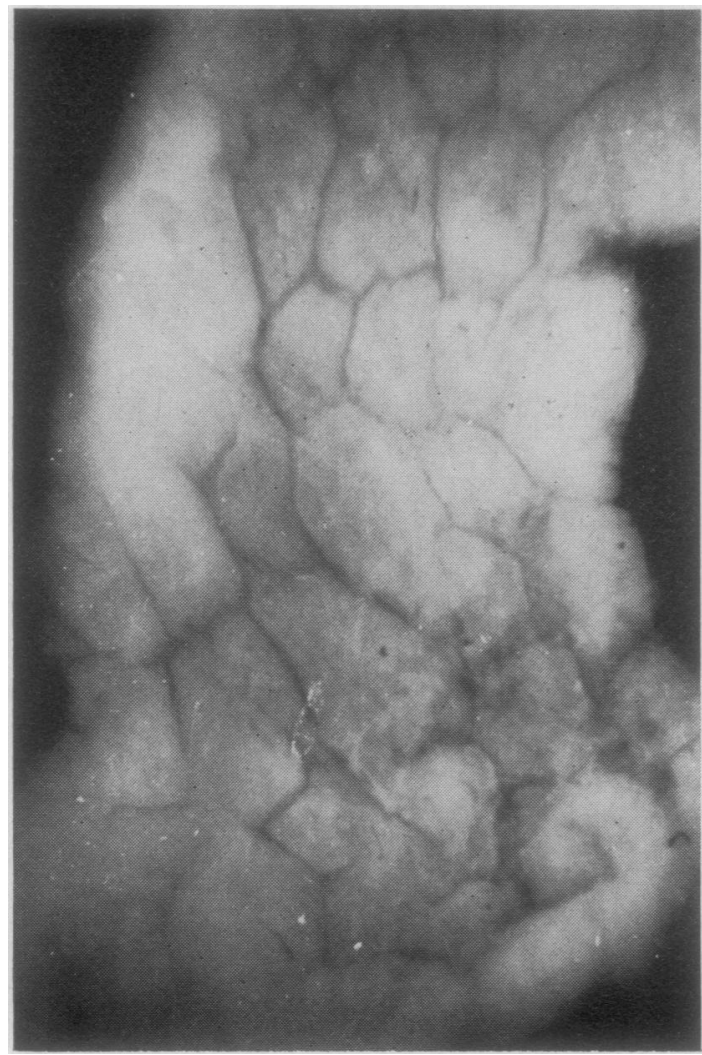

Fig 1 Flat mosaic mucosa. Dissecting microscope.

\section{Results}

MUCOSAL APPEARANCE OF THE SMALL INTESTINE

\section{Diet containing gluten}

There were six patients with adult coeliac disease on a free diet containing gluten who showed a flat mucosa (figs $1,2,3$ ) with or without a mosaic pattern in the upper third of the small intestine and in the duodenum (table I). Convolutions (figs 4 and 5 ) and ridges involved the middle third of the small intestine and digitate (fig 6) and leaf villi were present in the distal third. Flat mucosa involved twothirds of the jejunum and ileum in case 2 and low convolutions were present in the distal third.

The mucosal lesion was sometimes patchy in distribution. In case 2 a random biopsy taken during postmortem examination from the duodeno-jejunal flexure was examined immediately and showed digitate and leaf villi. Dissecting microscopy of the entire specimen on the next day revealed flat mucosa with a mosaic pattern covering approximately two-

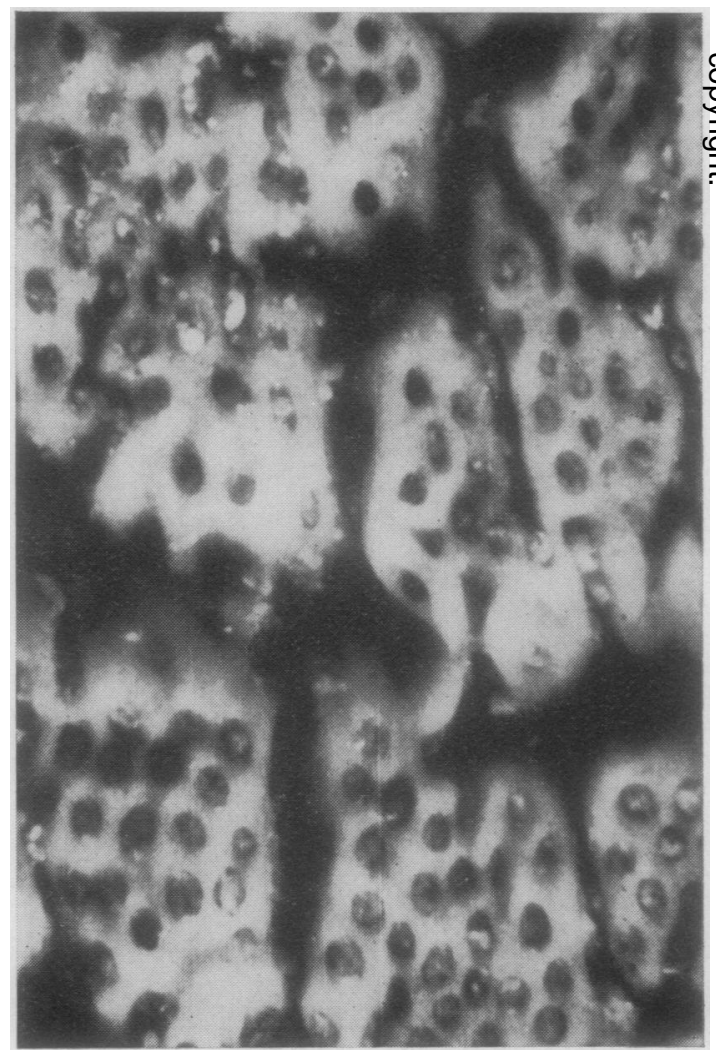

Fig 2 Flat mosaic mucosa. Dissecting microscope. 
Necropsy studies on adult coeliac disease

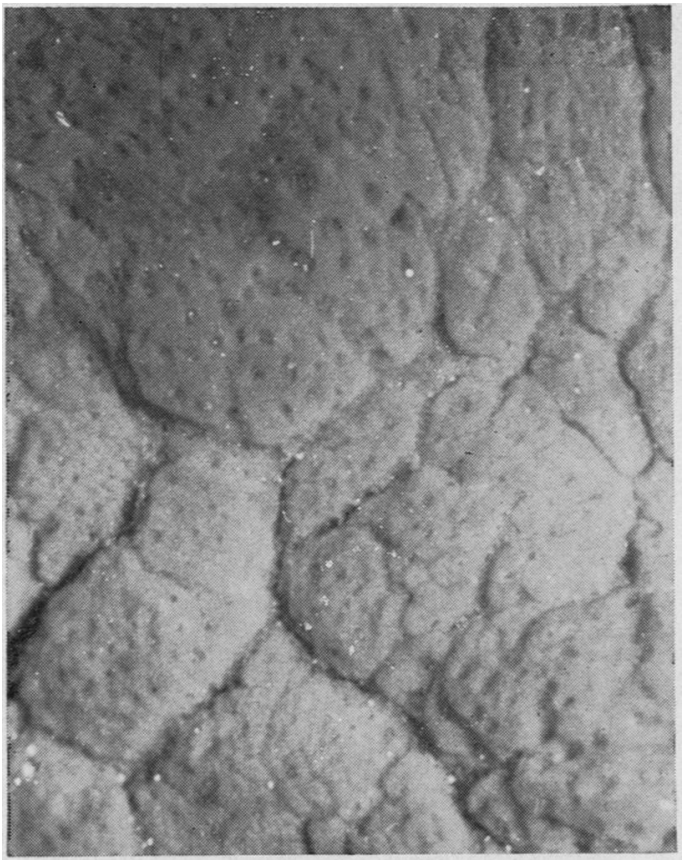

Fig 3

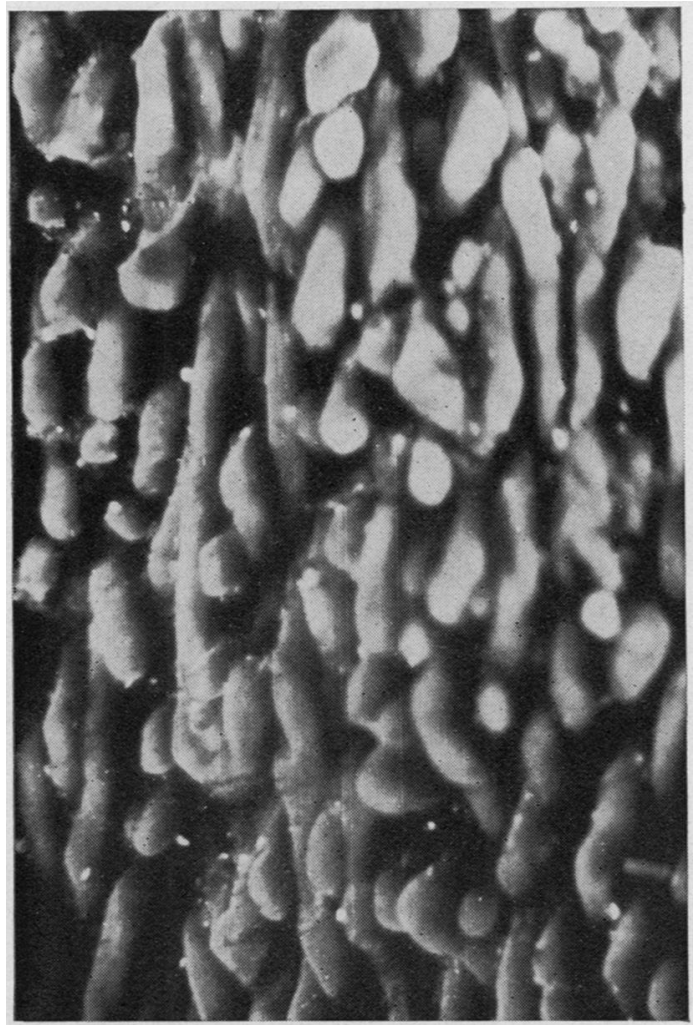

Fig 5
Fig 3 Flat mucosa with trace of mosaic pattern. Dissecting microscope.

Fig 4 Convolutions. Dissecting microscope.

Fig 5 Convolutions, ridges, leaf and vigitate villi. 


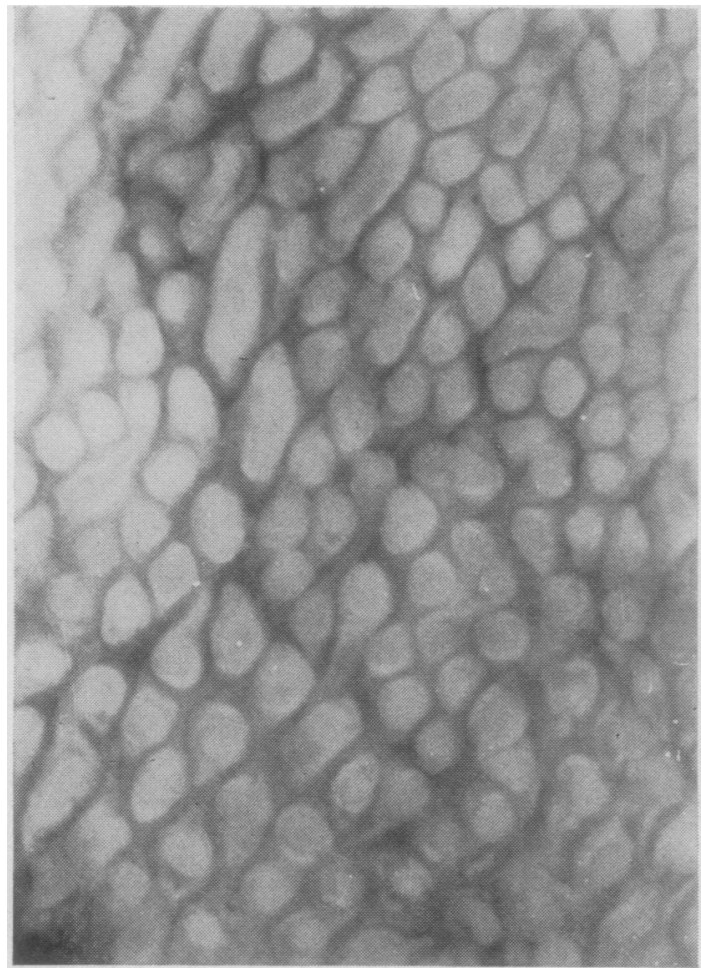

Fig 6 Normal digitate villi. Dissecting microscope.

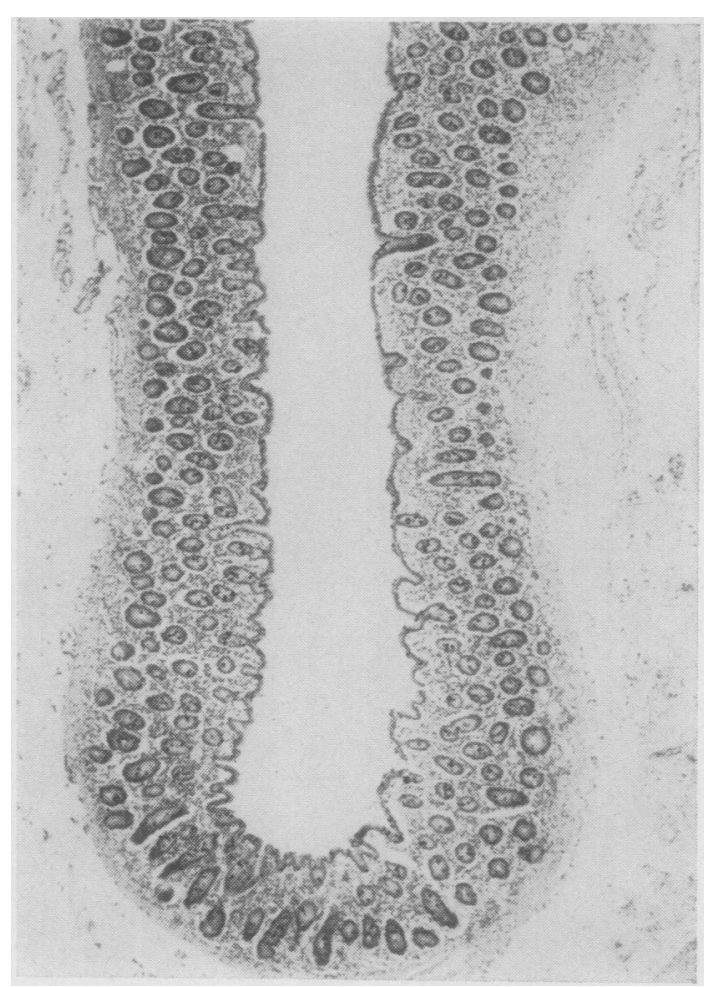

Fig 7 Grade 3 abnormality. $\times 40$.

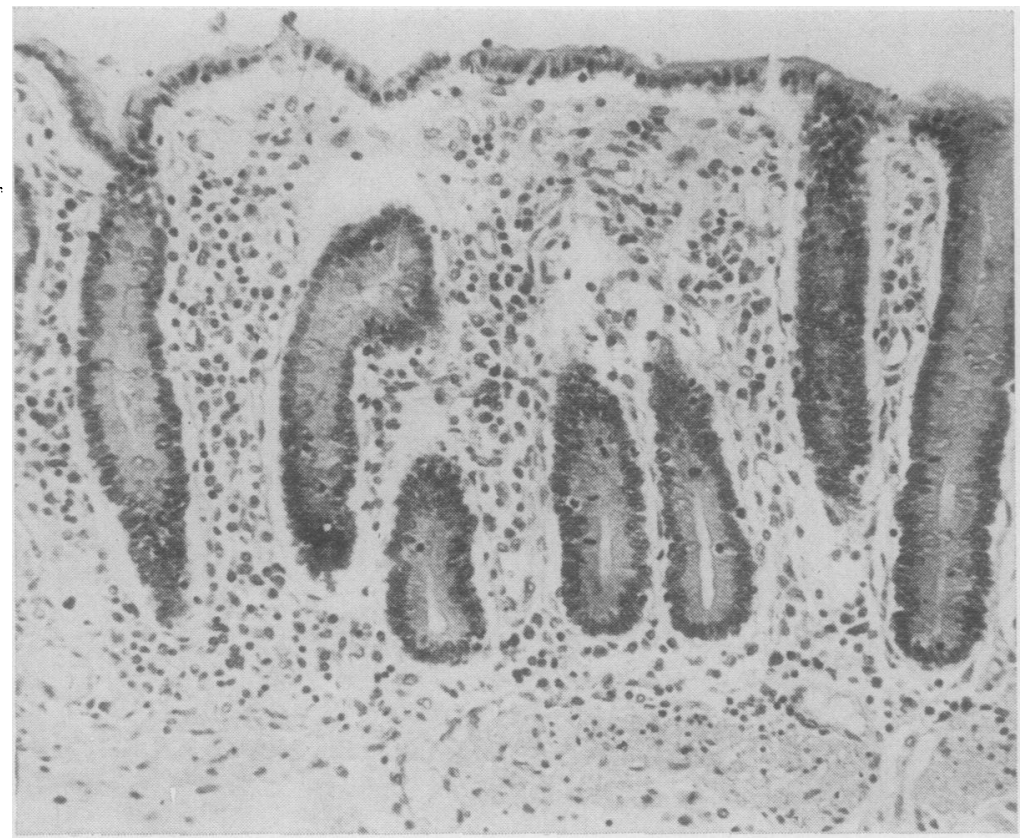

Fig 8 Grade 3 abnormality. $\times 400$. 

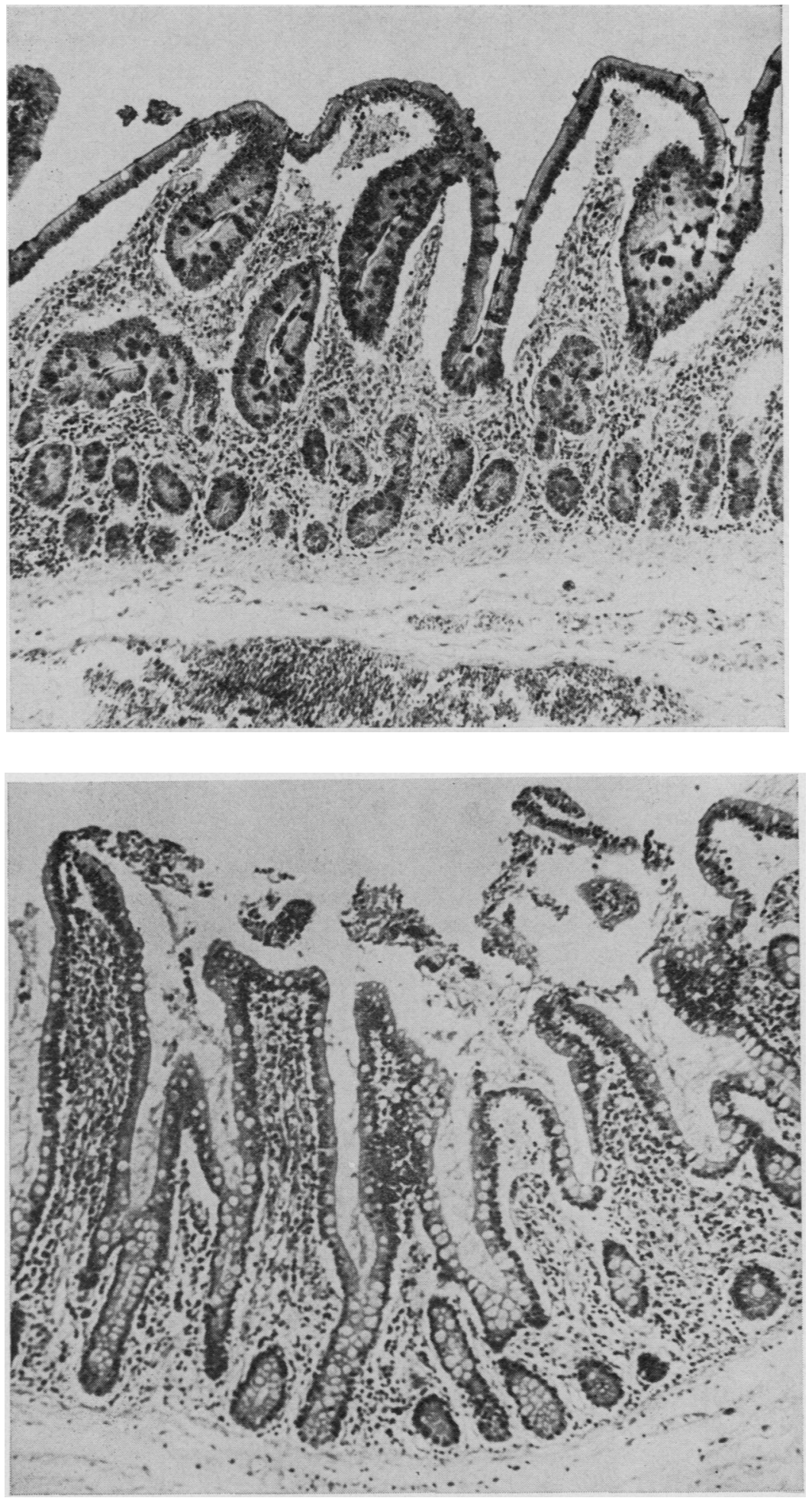

Fig 9 Grade 2 abnormality. $\times 160$.

Fig 10 Grade 1 abnormality. $\times 160$. 
thirds of the small intestine.

The random biopsy in this case was therefore grossly misleading. Transitional zones in particular showed an alternating villous pattern with areas of flat mucosa, convolutions, ridges, digitate and leaf villi. However, such heterogeneous areas formed only a small proportion of the major abnormality encountered in a particular segment. Villous abnormalities bore no constant relationship to the valvulae conniventes.

Histological examination confirmed that flat mucosa with or without a mosaic pattern and low convolutions corresponded to subtotal villous atrophy-grade 3 abnormality (figs 7 and 8). Convolutions and ridges with occasional leaf and digitate villi corresponded to partial villous atrophy_grade 2 abnormality (fig 9). Ridges, leaf and digitate villi with occasional convolutions represented grade $1 \mathrm{ab}-$ normality (fig 10). Digitate and leaf villi represented a normal villous pattern.

Surface epithelium was abnormal in appearance in flat and convoluted mucosa. The epithelium was more cuboidal than normal with lymphocytic infiltration. Rarely surface epithelium was abnormal in grade 1 abnormality but more usually it was normal in this grade.

Subepithelial hyalin was occasionally seen in association with the flat mucosal lesion. Chronic inflammatory cellular infiltration of the lamina propria was a constant feature. Crypt changes with mitoses and crypt hyperplasia were also seen. Occasional crypts were encountered undergoing dissolution and leucocytes were occasionally noted in the crypt lumen. Small areas of gastric metaplasia were found in the duodenum and jejunum. The distribution of Paneth cells and argentaffin cells was not abnormal in this series.

\section{Gluten-free diet}

There were 18 patients who had been treated with a gluten-free diet and the clinical response in each case is assessed in table I. Necropsy revealed no evidence of flat mucosa in six of these cases. Complete restoration of villous architecture was observed in one case only and it is of some interest that this patient died four years later from reticulum cell sarcoma of the stomach. Convolutions persisted in the other five cases with grade 2 abnormality involving up to $69 \%$ of the intestinal mucosa.

A good clinical response to a gluten-free diet was obtained in another five patients but flat mucosa persisted in the jejunum involving between 6 and $12 \%$ of the mucosal surface. It is possible in these cases that gluten had not been completely eliminated from the diet.

Three patients responded poorly to a gluten-free diet, and this was correlated with persistent flat mucosa at necropsy involving up to $70 \%$ of the mucosa so that these could be described as resistant cases of adult coeliac disease. It is known that one of these patients (case 9) did not stick to her glutenfree diet and dietary indiscretion may have occurred in the other two cases.

There were four other cases in which the response to a gluten-free diet was not fully assessed since treatment lasted for six months or less. Two of these patients did give a temporary response to a glutenfree diet but they died from reticulum cell sarcoma before a complete response had been obtained.

\section{Complications}

\section{MALIGNANCY}

Malignant lymphoma was demonstrated in 10 of our 24 necropsy cases and has been described by Harris et al (1967) and Cooke (1968). Many of these patients have had coeliac disease for more than 20 years and some have been treated with a gluten-free diet. Other patients have had a short history of adult coeliac disease and it is probable that coeliac disease had been present for many years in an occult or latent form. The tumour occurs as a multicentric lesion with circumferential ulcerating lesions (fig 11), as a solitary ulcerating lesion, or as small nodules in the mucosa. In some cases, there is no evidence of intestinal involvement although malignant lymphoma was identified in the mesenteric lymph nodes, liver, or other regional lymph nodes. Occasionally the stomach is the site of malignant lymphoma. Histological studies show that the lymphoma is a reticulum cell sarcoma (fig 12) although Reed Sternberg cells may be so prominent that the cytological features resemble those of Hodgkin's disease (fig 13).

Ulceration and perforation of intestinal lesions is a serious hazard. Perforating lesions may be difficult to differentiate from simple ulceration but the appearances of neoplastic reticulum cells infiltrating the muscle coat at the edge of the perforation is a characteristic feature although no solid tumour may be recognizable. Some of our cases of malignant lymphoma could not have been detected without a postmortem examination.

In this series, the primary site was identified as small intestine in seven cases (jejunum two, mid ileum four, terminal ileum one), stomach in one case, and lymph nodes in two cases. Multiple lesions were present in the gastrointestinal tract in seven cases. Metastases were found in seven cases. It is particularly interesting that perforation occurred in four cases.

Patients with malignant lymphoma who have had a surgical resection or who have been treated with 


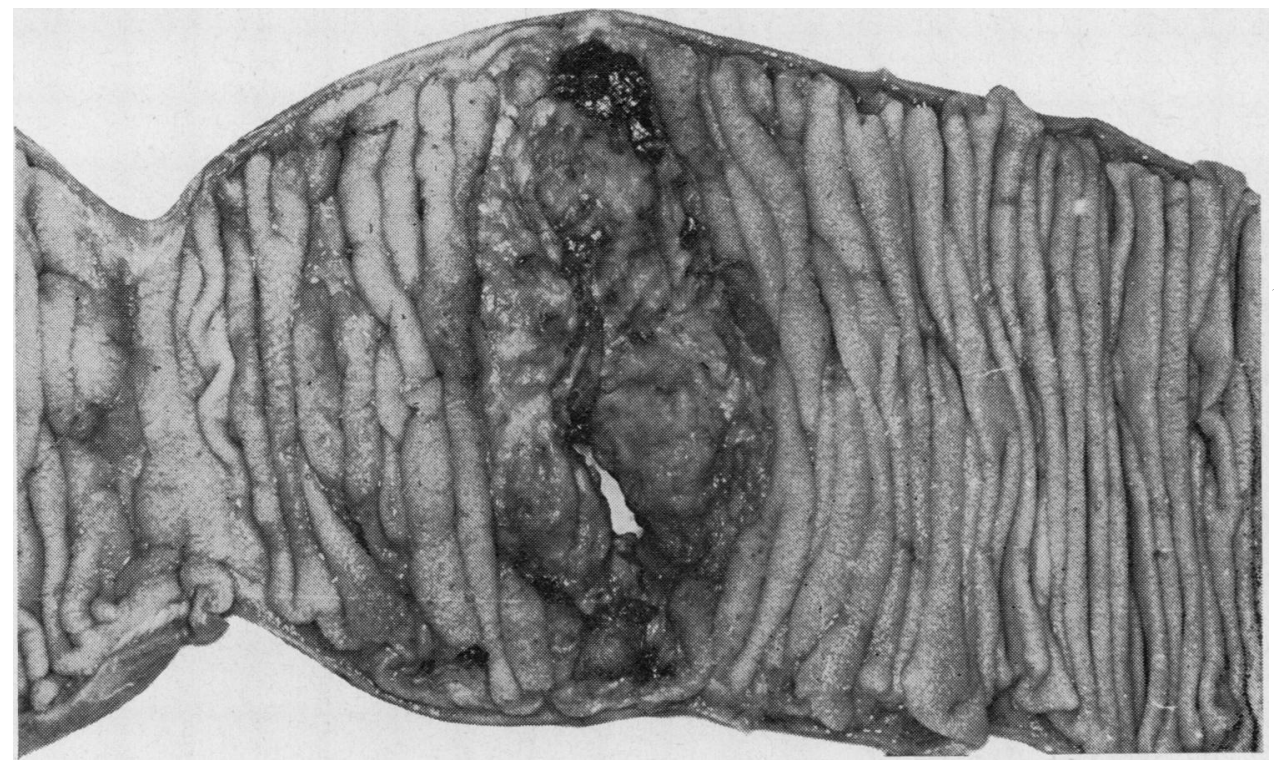

Fig 11 Ulcerated reticulum cell sarcoma of jejunum.

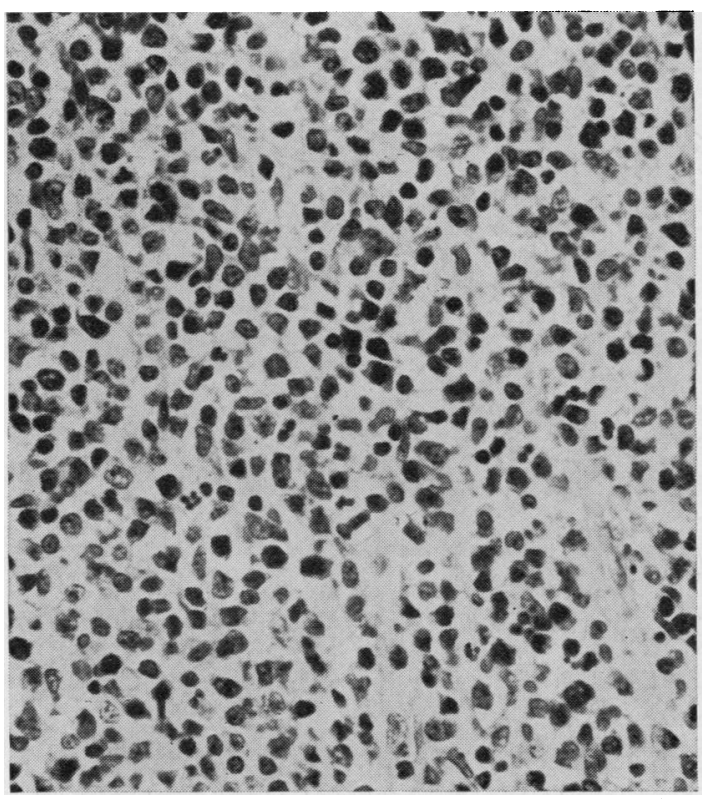

Fig 12

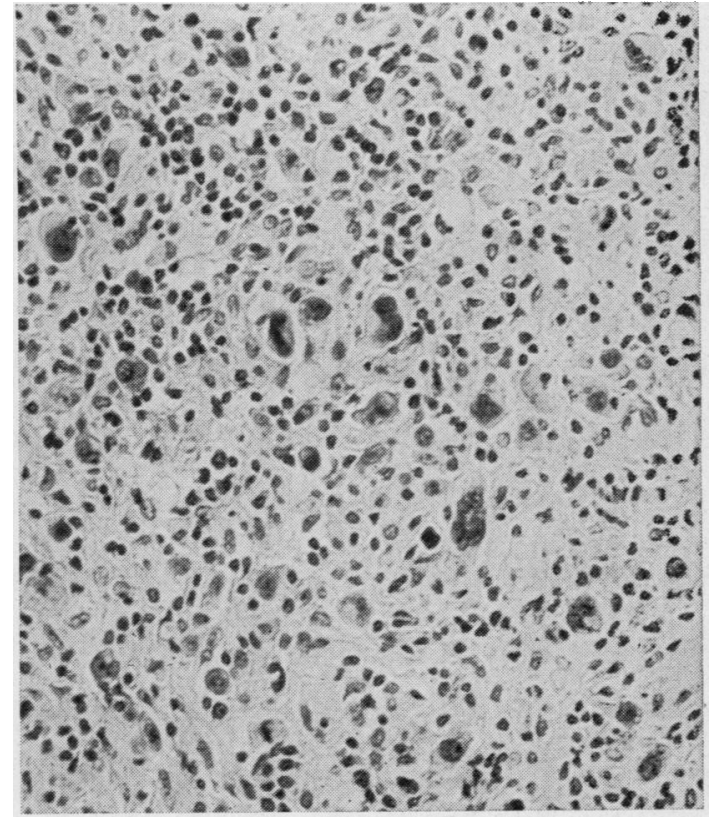

Fig 13

Fig 12 Reticulum cell sarcoma. $\times 400$

Fig 13 Reticulum cell sarcoma with Reed Sternberg giant cells. $\times 300$. 
cytotoxic drugs or radiation therapy may have no residual evidence of lymphoma at necropsy. In two of our cases there was persistent ulceration of the small intestine and it seems possible that the neoplastic cells had been destroyed.

Reticulum cell sarcoma usually shows evidence of reticulin production and occasionally slight fibrosis. In some cases there may be no evidence of reticulin formation but the degree of nuclear pleomorphism enables one to classify the tumour as a reticulum cell sarcoma rather than as a lymphosarcoma. Plasma cell differentiation is noteworthy in some of these lymphomas and it is of particular interest that Brunt, Sircus, and MacLean (1969) have reported two cases of adult coeliac disease complicated by plasmacytosis of the small intestine. Plasma cells normally develop from lymphocytes or from plasma cell precursors, and it is of great interest that plasma cell differentiation can occur in this variety of neoplasia since it provides a link with the $1 \mathrm{~g} \mathrm{~A}$ and $1 \mathrm{~g} \mathrm{M}$ plasma cells in the lamina propria in adult coeliac disease. Malignancy may be associated with alteration in the serum immunoglobulin levels.

In one of our cases of untreated adult coeliac disease we discovered a microscopic focus of reticulum cell hyperplasia in the mucosa of the small intestine. This could represent a microscopic lymphoma.

We have not encountered premalignant changes in the lymph nodes, and, with reference to pleomorphic reactive changes seen in lymph nodes in diverse clinical disorders, eg, rheumatoid arthritis, toxoplasmosis, measles, hydantoin therapy, we would regard the prelymphomatous changes as extremely dubious. We are aware that certain lymphomas have a long and natural history, eg, mycosis fungoides, giant follicle lymphoma, and Hodgkin's disease but at the moment there are insufficient diagnostic criteria to suggest that this applies to lymphomas complicating adult coeliac disease. We have only one survival in our clinical series and this was a case of lymphoma of the cervical lymph nodes in a young man with adult coeliac disease. He was cured by surgical excision and radiation therapy. It is clear therefore that there is a high mortality rate from lymphoma in this disease entity.

Squamous carcinoma of the oesophagus is a recognized complication and we have confirmed this in one of our necropsy cases. We have also encountered gastric carcinoma and carcinoma of the colon. Carcinoma of the small intestine was not observed in our necropsy series but we have encountered three cases in our clinical series.

The increased incidence of carcinoma is also difficult to explain and suggests an increased suscepti-

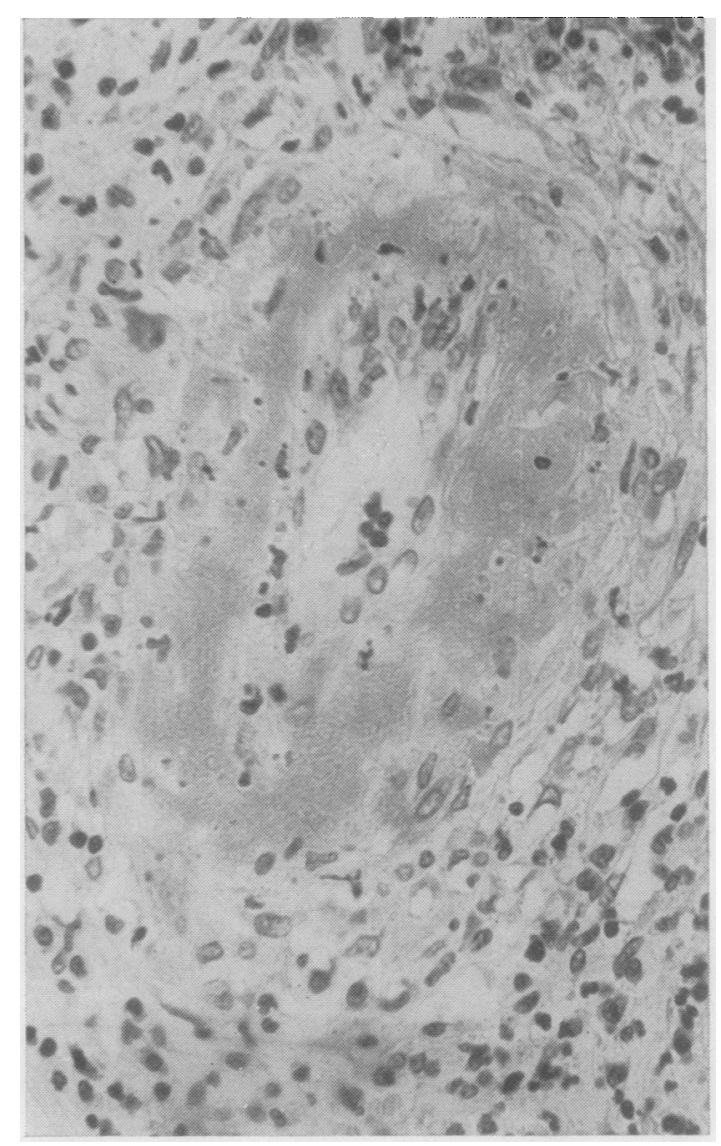

Fig 14 Polyarteritis nodosa. $\times 400$

bility to neoplasia, particularly in the gastrointestinal tract.

\section{ULCERATION}

Ulceration was encountered in the small intestine in five cases in this series and proved to be a fatal complication in two. Polyarteritis nodosa (fig 14) was responsible for ulceration in one patient who died from gastrointestinal haemorrhage. Widespread superficial ulceration of unknown aetiology led to progressive deterioration, failure to respond to a gluten-free diet, and death from postoperative complications in another case. Small ulcers were identified in the small intestine in the other three cases as an incidental finding at necropsy. No strictures were observed in the necropsy series but scars were noted in four cases.

\section{MUCOSAL DIAPHRAGMS}

Non-obstructing mucosal diaphragms (fig 15) representing exaggerated volvulae conniventes were 
Fig 15 Intestinal diaphragms.

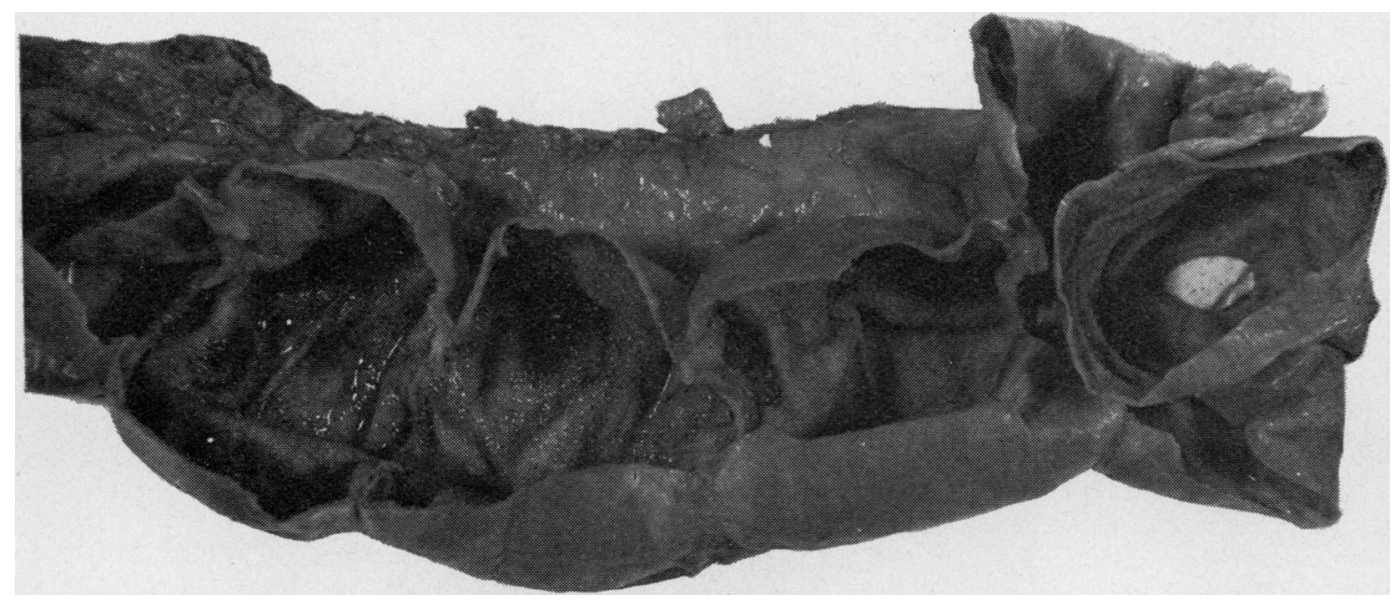

present in four necropsy cases. A bypass operation had been carried out in one case in which the diaphragms were identified during laparotomy and thought to present an obstructive problem. These diaphragms represent a congenital anomaly and they may be located in the upper jejunum, duodenum, or, occasionally, in the middle of the small intestine. They are usually multiple and may be distributed in pairs. Sacculation of the small intestine may occur in association with diaphragms.

\section{PIGMENTATION}

Brownish pigmentation of the small intestine is a prominent feature in untreated cases and it may also be encountered in patients who have been on a gluten-free diet. This was a feature in nine cases in our series. Histological examination reveals brownish-black lipofuscin pigment granules in the muscle cells of the muscularis propria, particularly the external coat. The pigmentation is due to vitamin $\mathrm{E}$ deficiency and this can be treated and reversed by alpha tocopherol therapy. This type of pigmentation, 'brown bowel', is not specific for coeliac disease since it may be encountered in other malabsorption states such as Crohn's disease or the postgastrectomy syndrome. Special stains such as PAS show up the pigment. In these cases it is probable that muscle atrophy may also be present and the role of autonomic neuropathy as described by Smith (1972) has to be assessed.

Two fatal cases have occurred in our series. In one patient the sigmoid colon had undergone volvulus, and in the other several loops of the small intestine were involved. Death occurred in both cases before surgery could be undertaken.

ASSOCIATED GASTROINTESTINAL DISEASE

One patient in this series also had ulcerative colitis. Crohn's disease has not been encountered in this series.

LYMPHORETICULAR ATROPHY

Lymphoreticular atrophy with a small spleen weighing under $100 \mathrm{~g}$ was noted in 10 necropsies in this series. It is noteworthy that four patients with lymphoreticular atrophy developed malignant lymphoma.

\section{SKIN ERUPTIONS}

None of our patients suffered from dermatitis herpetiformis. Two cases, however, developed a non-specific recurrent skin eruption. One further patient developed eczematous skin lesions which represented metastatic reticulum cell sarcoma.

\section{INFECTION}

Bronchopneumonia was a common terminal complication and was present at necropsy in 11 cases.

\section{OTHER COMPLICATIONS}

Metabolic bone disease, principally osteomalacia and neuropathy, occurred in some of these cases but clinical and pathological details are reported elsewhere. 


\section{Discussion}

These studies confirm the observation of Hourihane (1963) and of MacDonald et al (1964) that the flat mucosal lesion in adult coeliac disease involves the jejunum and duodenum and only occasionally extends into the ileum. It is also clear that although a good clinical response to a gluten-free diet may be associated with a return to a normal villous architecture or grade I abnormality, the flat mucosal lesion persists to a lesser extent in a proportion of cases. This could be due to the persistence of small amounts of gluten in an otherwise gluten-free diet or to other unknown factors. Complications such as malignancy or ulceration may be associated with failure to respond to a gluten-free diet or with relapse of symptoms but it is of great interest that one of our patients with lymphoma (case 13) gave an excellent response to a gluten-free diet (Cooke, Thompson, and Williams, 1969).

The high incidence of neoplasia in this necropsy series, as well as in the clinical series described by Harris et al (1967), reinforces the view that malignancy is a lethal complication of adult coeliac disease. Several cases in the series could not have been identified without postmortem examination. The emergence of reticulum cell sarcoma in 10 cases is particularly noteworthy and suggests a defect in the immune surveillance mechanism or viral oncogenesis. It is of interest that reticulum cell sarcoma developed in three patients who had been on a gluten-free diet for four, nine, and 15 years respectively with a good clinical and histological response.

It has been suggested by Creamer (1964) that coeliac disease is a complication of malignancy but there is little evidence to support this contention. Many of our patients had a long history of adult coeliac disease before developing malignancy. With reference to those patients with a short history of adult coeliac disease and malignancy, it seems more likely to us that they represent occult or unrecognized cases of adult coeliac disease. Observations on dermatitis herpetiformis by Marks, Shuster, and Watson (1966) show that the flat mucosal lesion can exist in an occult manner, and it is probable that adult coeliac disease is more common in the community than most of us realize.

Bayless, Kapelowitz, Shelley, Ballinger, and Hendrix (1967) and Goulston, Skyring, and McGovern (1965) have drawn attention to ulceration as a dangerous complication of adult coeliac disease. Two fatal cases in this series support this view. Small ulcers, however, may be encountered as an unexpected incidental finding in patients with adult coeliac disease in necropsy material.

The occurrence of two fatal cases of volvulus is noteworthy but the incidence in larger clinical series needs to be assessed before it can be substantiated that this is yet another complication of adult coeliac disease.

Lymphoreticular atrophy has been documented as a complication of adult coeliac disease by Martin and Bell (1965), McCarthy, Fraser, Evans, and Read (1966), Ferguson, Hutton, Maxwell, and Murray (1970), and by Marsh and Stewart (1970), and also as a complication of dermatitis herpetiformis by Pettit, Hoffbrand, Seah, and Fry (1972). It seems probable that there could be altered immunological reactions in such patients.

It is hoped that these observations will stimulate other researchers in adult coeliac disease to assess the response of intestinal mucosa to treatment not only during life but also at necropsy.

My thanks are due to $\mathrm{Dr} \mathrm{W}$. T. Cooke who was responsible for all clinical studies on these cases, to Mr David Pugh, and Mr Leslie Ellis for their expert histological assistance, and to $\mathrm{Mr}$ Jones for the photographic work. I am also grateful to the Endowment Research Fund which provided a grant for technical assistance.

\section{References}

Adlersberg, D., and Schein, J. (1947). Clinical and pathological studies in sprue. J. Amer. med. Ass., 134, 1459-1467.

Bayless, T. M., Kapelowitz, R. F., Shelley, W. M., Ballinger, W. F., and Hendrix, T. R. (1967). Intestinal ulceration-a complication of celiac disease. New Engl. J. Med., 276, 996-1002.

Boels, W., and Tverdy, G. (1950). Anatomopathologie de L'intestin grêle dans les diarrhées graisseuses idiopathiques. Acta gastroent. belg., 13, 481-505 (supplement, 1, 83-107).

Brunt, P. W., Sircus, W., and MacLean, N. (1969). Neoplasia and the coeliac syndrome in adults. Lancet, 1, 180-186.

Cooke, W. T. (1968). Adult coeliac disease. Prog. Gastroent. 1, 299-338.

Cooke, W. T., and Brooke, B. N. (1955). Non-specific enterocolitis. Quart. J. Med., 24, 1-22.

Cooke, W. T., Fone, D. J., Cox, E. V., Meynell, M. J., and Gaddie, R. (1963). Adult coeliac disease. Gut, 4, 279-291.

Cooke, W. T., and Smith, W. T. (1966). Neurological disorders associated with adult coeliac disease. Brain, 89, 683-722.

Cooke, W. T., Thompson, H., and Williams, J. A. (1969). Malignancy and adult coeliac disease. Gut, 10, 108-111.

Creamer, B. (1964). Malignancy and the small-intestinal mucosa. Brit. med. J., 2, 1435-1436.

Dymock, I. W., and Gray, B. (1968). Staining method for the examination of the small intestinal villous pattern in necropsy material. J. clin. Path., 21, 748-749.

Ferguson, A., Hutton, M. M., Maxwell, J. D., and Murray, D. (1970). Adult coeliac disease in hyposplenic patients. Lancet, 1, 163-164.

Goulston, K. J., Skyring, A. P., and McGovern, V. J. (1965). Ulcerative jejunitis associated with malabsorption. Austral. Ann. Med., 14, 57-64.

Harris, O. D., Cooke, W. T., Thompson, H., and Waterhouse, J. A. H. (1967). Malignancy in adult coeliac disease and idiopathic steatorrhoea. Amer. J. Med., 42, 899-912.

Himes, H. W., Gabriel, J. B., Adlersberg, D. (1957). Previously undescribed clinical and postmortem observations in nontropical sprue; possible role of prolonged corticosteroid therapy. Gastroenterology, 32, 60-71. 
Hourihane, D. O'B. (1963). The histology of intestinal biopsies. Proc. roy. Soc. Med., 56, 1073-1077.

McCarthy, C. F., Fraser, I. D., Evans, K. T., and Read, A. E. (1966). Lymphoreticular dysfunction in idiopathic steatorrhoea. Gut, $7,140-148$.

MacDonald, W. C., Brandborg, L. L., Flick, A. L., Trier, J. S., and Rubin, C. E. (1964). Studies of celiac sprue IV. The response of the whole length of the small bowel to a gluten-free diet. Gastroenterology, 47, 573-589.

Marks, J., and Shuster, S. (1971). Intestinal malabsorption and the skin. Gut, 12, 938-947.

Marks, J., Shuster, S., and Watson, A. J. (1966). Small-bowel changes in dermatitis herpetiformis. Lancet, 2, 1280-1282.

Marsh, G. W., and Stewart, J. S. (1970). Splenic function in adult coeliac disease. Brit. J. Haemat., 19, 445-457.

Martin, J. B., and Bell, H. E. (1965). The association of splenic atrophy and intestinal malabsorption. Canad. med. Ass. J., 92, 875-878.

Paulley, J. W. (1954). Observations on the aetiology of idiopathic steatorrhoea. Brit. med. J., 2, 1318-1321.

Pettit, J. E., Hoffbrand, A. V., Seah, P. P., and Lionel Fry. (1972) Splenic atrophy in dermatitis herpetiformis. Brit. med. J., 2, 438-440.

Roy-Choudhury, D. C., Cooke, W. T., Tan, D. T., Banwell, J. G., and Smits, B. J. (1966). Jejunal biopsy: criteria and significance. Scand. J. Gastroent., 1, 57-74.

Royer, M., Croxatto, O. C., Biempica, L., and Balcazar-Morrison, A. J. (1955). Biopsia duodenal por aspiración bajo control radioscópico. Prens. med. argent., 42, 2515-2519.

Shiner, M. (1956). Duodenal biopsy. Lancet, 1, 17-19.

Shuster, S., Watson, A. J., and Marks, J. (1968). Coeliac syndrome in dermatitis herpetiformis. Lancet, 1, 1101-1106.

Smith, B. F. (1972). Neuropathology of the Alimentary T:act. Arnold, London.

Thaysen, T. E. H. (1932). Non-Tropical Sprue. Levin and Munksgaard, Copenhagen. Humphrey Milford, London.

Wilding, P., Cooke, W. T., and Nicholson, G. I. (1964). Globulinbound amylase. Ann. intern. Med., 60, 1053-1059.

\section{Addendum}

Since this paper was written three further cases have been examined by formalin distension technique within two hours of death.
CASE 25

Male, aged 70, was diagnosed as adult coeliac disease with flat jejunal biopsy in 1964 . He was treated with a gluten-free diet for nine years and there was a good response although it is known that he did not stick to his gluten-free diet. He died in 1973 from bacterial endocarditis, bronchopneumonia, and squamous carcinoma of the palate with lymph node metastases. Small intestine, $382.5 \mathrm{~cm}$ in length, showed prominent non-obstructing diaphragms. Slight lipofuscin pigmentation and lymphoreticular atrophy were noted: grade $167 \cdot 3 \%$, grade $229.2 \%$, grade $33.5 \%$.

CASE 26

Female, aged 78, was diagnosed as idiopathic steatorrhoea in 1942 and as adult coeliac disease with flat biopsy in 1961. She was treated with a gluten-free diet in 1965 and had a good response although she did not stick to the diet. She died in 1974 from bronchopneumonia, acute pyelonephritis, and cerebral softening. Small intestine, $694 \mathrm{~cm}$ in length: grade $191 \cdot 1 \%$, grade $28.9 \%$, grade 30 . Lymphoreticular atrophy noted.

\section{CASE 27}

Male, aged 58, was diagnosed as adult coeliac disease with flat biopsy in November 1973. A gluten-free diet instituted with poor clinical and histological response. He was an alcoholic who did not stick to his gluten-free diet. Died in February 1974 from pulmonary embolism and cerebral softening. Small intestine, $559 \mathrm{~cm}$ : grade $116.2 \%$, grade $251.5 \%$, grade $332.3 \%$. Early incomplete response. Found also to have chronic pancreatitis. 